\title{
Ugledališčenje spominov na primeru Pahorjevih romanov Spopad s pomladjo in Nekropola
}

Ključne besede: Boris Pahor, spomini, pričevanjska literatura, koncentracijsko taborišče, gledališče

DOI: $10.4312 /$ ars.12.2.176-187

Boris Pahor je spomine na čas, preživet v nacističnih koncentracijskih taboriščih, vtkal že v zbirko črtic Moj tržaški naslov (1948), prvič je o njih obširneje pisal v romanu Onkraj pekla so ljudje (1958), najbolj celostno pa jih je ubesedil v romanu Nekropola (1967). Pot do izida in priznanja Nekropole - najprej v Franciji, nato v Sloveniji in Italiji - sta spremljala prezrtje in zavračanje. ${ }^{1}$ Pahor je svoj roman poslal v branje med drugim tudi avtorju pričevanjske literature Primu Leviju, vendar odgovora ni prejel. Leta 1995 je pri založniški hiši Phoebus, ki je pred tem uspešno plasirala Bartolov roman Alamut, v francoskem prevodu izšel Pahorjev roman Spopad s pomladjo, ${ }^{2}$ kar »je za seboj retroaktivno potegnilo tudi Nekropolo« (Bavčar, 2011, 15). Ta je v Franciji (neopaženo) izšla leta 1990. Preboj na francoski in nemški knjižni trg, ki je sovpadel $\mathrm{z}$ zanimanjem ${ }^{3}$ za literaturo $\mathrm{s}$ taboriščno tematiko, je povzročil spremembo tudi $\mathrm{v}$ recepciji slovenske literarne kritike ter številne prevode v druge jezike. ${ }^{4}$

Romanoma je skupen modus priklicevanja preteklosti, vendar Nekropolo od Spopada s pomladjo, ki ima v ospredju ljubezensko zgodbo, razlikujeta prvoosebni pripovedovalec ter prevladujoči pričevanjski diskurz. ${ }^{5}$ Barel Lang (v: Latković, Kovač,

1 Dušan Pirjevec in Taras Kermauner sta bila kritična do njegovega pričevanjskega diskurza in poudarjanja nacionalne problematike.

2 Roman je bil ob izidu leta 1958 naslovljen Onkraj pekla so ljudje, vendar se je avtorju naslov sčasoma zazdel preveč »neizpodbiten, kajti tudi upravljalci taborišč, katerih se je junak tega spisa rešil, so bili, čeprav skaženi, še zmeraj ljudje« (Pahor, 1978, 2). Ob tem je treba dodati, da je Pahor roman tudi nekoliko predelal. Leta 1978 je tekst s prvotnim naslovom izšel v samozaložbi, saj se je Pahorjev status oporečnika radikaliziral po objavi intervjuja s Kocbekom v reviji Zaliv, kar je oteževalo izdajanje njegovih romanov.

3 Simona Škrabec $(2011,141)$ ocenjuje, da je zavest o dediščini literarnih pričevanj iz nacističnih taborišč "povsod rasla izjemno počasi« in tudi v literarni teoriji so tovrstni teksti »zaradi svoje boleče zavezanosti preveč resničnim dogodkom obležal[i] nekje na robu književnosti kot zgolj stvarna pričevanja«.

4 Prevod v nemščino (2001), srbščino (2009), hrvaščino (2012) in makedonščino (2014).

5 Med pričevanjsko literaturo o taboriščni izkušnji spadajo teksti Prima Levija, Roberta Antelma, Simone Alizon, Jorgeja Semprúna, Imreja Kertésza, Ruth Klüger, Davida Rousseta in mnogih drugih. 
2011, 31) ponuja eno od možnih klasifikacij pričevanjske literature o holokavstu, pri čemer razlikuje med tremi temeljnimi skupinami besedil, ki jih razvršča glede na njihovo stopnjo prilikovanja zgodovini. V prvo skupino, kamor umeščam Pahorjeva romana, spadajo besedila, ki želijo biti zgodovinsko verodostojna, vendar se hkrati distancirajo od "čistih" zgodovinskih besedil, pri čemer poudarjajo subjekt izrekanja. Druga skupina zajema besedila, ki napotujejo na zgodovino s kontekstom ali podtekstom in predpostavljajo bralčevo poznavanje holokavsta, zato $\mathrm{k}$ temi pristopajo neposredno; kontekst in podtekst pa imata poudarjeno funkcijo literarnega postopka. Sem spada poezija. V tretjo skupino, ki jo opredeljuje težnja po verodostojnosti prikazovanja zgodovine, Lang umešča zgodovinska besedila (Latković, Kovač, 2011, 31).

Neglede na umestitevv posamezno žanrsko skupino besedila o holokavstu nenehno sprožajo vprašanja o avtentičnosti prikazanega in zbujajo načelni dvom o možnosti ubeseditve travmatične taboriščne izkušnje; oboje je tesno povezano z nihanjem med zgodovinskim in umetniškim modusom prikazovanja (Latković, Kovač, 2011, 31). Tudi Pahor na več mestih v Nekropoli prevprašuje človekovo zmožnost spominjanja in ubeseditve taboriščne izkušnje:

$\mathrm{V}$ čistem soncu so zdaj te podobe nemogoče in zavedam se, da so naše raztepene procesije za zmeraj prešle v neresnično ozračje preteklosti (Pahor, 1997, 35).

Po njegovem mnenju niti fotografije internirancev ne bi mogle "podati razpoloženja človeka, kateremu se zdi, da je njegov sosed dobil v železni skledi za pol prsta več rumene tekočine« (Pahor, 1997, 14). Edino filmska kamera bi lahko verodostojno posnela takšne sekvence, vendar - zapiše Pahor - je bolje, da takega filma ne bi bilo.

Nekropolo s preostalo pričevanjsko literaturo povezuje tudi pripovedovalčev občutek sramu, krivde oziroma nečistosti zaradi lastnega preživetja, saj je jedel kruh mrtvih. $\mathrm{V}$ tem smislu smemo razumeti citat oziroma posvetilo $\mathrm{z}$ začetka romana Manom vseh tistih, ki se niso vrnili. Pahor $(1997,91)$ eksplicitno zapiše: "Živ sem, zato so tudi moja najbolj pristna čustva nekje nečista. « Marija Jurić Pahor $(2008,9) \mathrm{v}$ razpravi o narativni oziroma diskurzivni konstituciji spominjanja ter o "geno-tekstu simbolizacije« (Julia Kristeva), ki temelji na predjezikovni artikulaciji, povezani $\mathrm{z}$ modaliteto primarnega procesa, raziskuje, kako se ta artikulacija razodeva $\mathrm{v}$ pričevanjski literaturi preživelih iz koncentracijskih taborišč. Potrebo pripovedovati drugim, o kateri je v knjigi Ali je to človek (1947) spregovoril Primo Levi, vzporeja $\mathrm{z}$ nujo po pisanju Borisa Pahorja, ki je terapevtsko ${ }^{6}$ vlogo te dejavnosti ozavestil

6 Pahor v intervjuju s Poljanko Dolhar in Maksimiljano Ipavec pravi: »Ko sem začel pisati - zapiske sem delal že v sanatoriju - sem želel samo pričevati. Povedati, kar sem doživel, da bi drugi izvedeli za grozote taborišč. Po desetletjih tega početja pa lahko rečem, da sem se s pisanjem hotel odkupiti. 
kasneje. Jurić Pahor pričevanja ne razume toliko kot razumsko hotenje in priučeno sposobnost, temveč kot navdihnjenje, ki travmatski spomin razkriva na živo nazoren način, kar je bolj v zvezi s katarzo kot z elaboracijo (zavestno oziroma ozaveščevalno dejavnostjo).

Eno pomembnejših sidrišč Pahorjevega pričevanja je telo, saj v taborišču - bivališču niča in senc - misli izginejo, ostanejo le telo in njegove lačne celice. Prvoosebnega pripovedovalca iz Nekropole in osrednjo književno osebo Radka Subana, povrnjenca iz nacističnega taborišča z izrazito avtobiografskimi potezami Borisa Pahorja, iz Spopada $s$ pomladjo povezuje pričevanje o izmučenem in razžaljenem telesu; nekateri motivi se $\mathrm{v}$ obeh romanih ponovijo, na primer postopek obredne ogolitve telesa, ki ga nacisti niso izvajali le zaradi higienskih razlogov, ampak ima tudi simbolni pomen. Marta Verginella $(2011,63)$ primerja opis tega obreda pri Leviju, Kertészu, Roussetu in Pahorju; za slednjega napiše, da

secira $z$ veliko zoprnostjo [...]. Prikaz taboriščne ogolitve je pri njem tako dramatično konkreten, da lahko sproža grozo, pri nekaterih celo gnus.

Vendar je razlika med Nekropolo in Spopadom s pomladjo v tem, da prvo besedilo tematizira propadanje, izsuševanje, onečaščanje telesa, drugo pa njegovo postopno oživljanje s pomočjo ljubezni.

Ravno telesnost in dialoškost sta tista inherentna teatralna in performativna elementa Pahorjeve pričevanjske literature, ki ponujata prenos v gledališki medij. Ta se je tudi uresničil, ko je režiser Marko Sosič leta 2006 v Slovenskem stalnem gledališču v Trstu uprizoril dramatizacijo Pahorjevega romana Spopad s pomladjo, ki jo je pripravil Igor Lampret, in čez štiri leta (2010) z uprizoritvijo Nekropole v Mestnem gledališču ljubljanskem v koprodukciji z društvom Celinka in KUD Pod topoli (dramatizacija in režija Boris Kobal).

$\mathrm{V}$ smislu prenosa $\mathrm{v}$ dramsko obliko in nato $\mathrm{v}$ gledališki medij ponuja roman Spopad s pomladjo več možnosti kot Nekropola. Roman v linearnem narativnem loku izpisuje zgodbo Radka Subana, povrnjenca iz nacističnega taborišča. Dogajanje se prične na začetku maja 1945 na vlaku, ki vozi skozi holandsko pokrajino, ter se nadaljuje $\mathrm{v}$ pariškem sprejemnem centru in nato $\mathrm{v}$ sanatoriju, kjer Suban postopno okreva. »Prebujanje«, »odpadanje skorje s telesa«, trganje iz »smrtne omame« in "smrtne megle«, v katero je še vedno ujet, so metaforični opisi njegovega spopadanja $\mathrm{s}$ spomini na travmatična doživetja $\mathrm{v}$ taborišču. Zmago življenja nad sencami smrti napove erotično prebujanje, ki ga v Subanu sproži mlada bolničarka Arlette

In drži, pisanje je bilo terapija. Verjetno sem se hotel s pisanjem instinktivno razbremeniti, predelati travmo, se rešiti. A tega sem se zavedel šele veliko kasneje, takrat nisem pisal zato, da bi mi bilo lažje« (Pahor v: Dolhar, Ipavec, 2013). 
Dubois. Z vzdrževanjem nenehne napetosti v romanu, ustvarjene s približevanjem in oddaljevanjem zaljubljencev, in zaradi različnosti svetov, iz katerih prihajata, ter travmatskih spominov - njegovih taboriščnih in njenih ljubezenskih - ta časovno in prostorsko relativno zamejena zgodba evocira prenos v drug medij (gledališki ali filmski). Možnost dramskega načina porajajo nenehno osciliranje odnosa med pripovednima osebama, Radkovo razpiranje razklane notranjosti (»On pred Nemčijo in po Nemčiji - kdo ve, ali se bosta ta dva človeka kdaj srečala.«) (Pahor, 2009, 101) in obsežen delež dialoškega materiala. Teatralni in performativni elementi, med katerimi izstopa poudarjena telesnost, pa ponujajo tudi možnost nedramskih strategij ugledališčenja romana.

Avtor dramske priredbe Igor Lampret se je odločil za prvo možnost dramatizacijo. ${ }^{7}$ Dramatizacija, ki jo je s spoštovanjem do romana in njegovega avtorja snoval dve leti, zvesto sledi literarni predlogi tako v razvoju zgodbe kot izpostavitvi vseh pomembnih romanesknih motivov; prerazporeditev dogajanja se pojavi izjemoma, v celoti je izpuščenih le nekaj poglavij. Lampretov izbor dialogov iz romana je premišljen, saj vtke $\mathrm{v}$ dramski tekst tiste, ki so bistveni za karakterizacijo lika, oziroma jih poenostavi in prilagodi dramski situaciji. Epizaciji se prirejevalec ni mogel (ali želel) izogniti, njena funkcija pa je seznanitev bralca/gledalca s protagonistovimi notranjimi dilemami, s spomini na boj za preživetje $\mathrm{v}$ taborišču, na zapore $\mathrm{v} » z i d n i h$ omarah«, na fašistični Trst in na občutenje krivde preživelih taboriščnikov. Lampret je za ubeseditev krajšega monologa pogosto uporabil različne dele romana, kar je vodilo v kakovostnejši dramski tekst od tistega, ki bi nastal z dobesednimi prepisi iz romana.

Roman:

Doma, je pomislil. [...] Res, čakajo ga domači, obolela rdečelasa sestrica Vidka, čaka ga osvobojena gmajna s svojimi dolinicami in borovci, a on je vendar skoraj bolj doma tukajle na tej rumeni in prašni planjavi (Pahor, 2009, 111).

[...]

A kdo bo vzel obuvalo, ki je simbol vsega zla in morda celo zlo samo. Tudi če bi bil francoski človek bos, ali ne bi rajši oral bos, kakor da bi si moral natakniti take škornje? (Pahor, 2009, 112).

[...]

Zakaj naj na primer misli na dom in si želi domov, ko ni več tam nikogar, komur bi mogel zaupati svoj obisk v peklu (Pahor, 2009, 117).

7 V besedi dramatizacija je vsebovana beseda drama; tudi večina strokovne literature pojem dramatizacija opredeljuje kot transformacijo (prenos, preobrazbo) nedramskega besedila (umetnostnega ali neumetnostnega, epskega ali lirskega) v dramsko obliko, namenjeno uprizarjanju. 
Dramatizacija:

RADKO <sam pri sebi $z$ rahlo ironijo > Doma ... Doma me res čakajo domači. Obolela sestra Vidka, osvobojena gmajna, doline, borovci. S kakšno gotovostjo sem omenil dom. Ko vendar ne čutim nobenega domotožja. In kaj mi je bilo, da sem šel prodajat te škornje: celo tukajšnji kmet bo raje oral bos kot v takšnem obuvalu, ki je simbol minulega zla, mogoče celo zlo samo? (Lampret, Pahor , 2005, 14).

Režiserjevo branje uprizoritvene predloge je bilo zavezujoče; Marko Sosič je večji del Lampretove dramatizacije ohranil, s črtanjem nekaterih prizorov pa je dosegel očitnejše kontrastiranje ljubezenskih scen s temačnimi sanatorijskimi, ki stopnjujejo tragiko preživelih taboriščnikov, s čimer je v predstavi vzpostavil ritem in napetost.

Inscenacija Pahorjevega romana je ravno zaradi velike mere zvestobe romaneskni predlogi na trenutke dajala vtis gledališke ilustracije. Čeprav je pretehtano in subtilno zajela bistvene značilnosti Pahorjeve poetike, je bilo to storjeno $\mathrm{v}$ škodo gledališkemu izrazu. ${ }^{8} \mathrm{Z}$ izpuščanjem številnih romanesknih opisov Subanovih notranjih bojev med spomini na preteklost in življenjem, ki se je odpiralo pred njim, je postala Subanova nezmožnost zaživeti z Arlette v predstavi manj motivirana kot $\mathrm{v}$ romanu.

Boris Pahor je v enem od številnih intervjujev, ki jih je opravil v zvezi z uprizoritvijo romana Spopad s pomladjo, poleg želje po realistično zasnovani predstavi izpostavil tudi njen didaktični učinek:

Mladi naj se naučijo, kaj pomeni beseda taborišče, kaj pomeni uničenje, anihilacija človeka v njem. [...] Iz ljubezenske strani bi želel, da bi se mladi naučili spoštovati človeško telo. Iz česar sledi tudi spoštovanje do ženske, ki je tista, ki daje življenje (Pahor v: Dolhar, 2006).

Vendar kljub vezanosti prirejevalca romaneskne predloge in režiserja na (gledališke) koncepte avtorja romana ter pietetnemu odnosu do njegovega ustvarjanja in njega samega niti dramatizacija niti uprizoritev nista mogli tako prepričljivo kot roman prikazati Subanovega spopadanja s spomini oziroma preteklostjo, s čimer je postal vprašljiv (celo) didaktični učinek predstave.

Uprizoritev $^{9}$ Pahorjeve pričevanjske literature pa ni povezana zgolj $\mathrm{z}$ obuditvijo spomina na življenje v koncentracijskih taboriščih, ampak jo moramo

8 Celo v eni od kritik - te so bile predstavi večji del naklonjene - najdemo ob vseh simpatijah do Lampretovega in Sosičevega dela - tovrstno mnenje: »[V] igri [si] sledijo dramski trenutki z nečim, ki je bližje pripovedovanju oziroma branju značilnejših odlomkov iz Pahorjevega teksta kot pa dramskemu dialogu ali samogovoru« (Mermolja, 2006).

9 Pred tem so leta 2004 v gledališču Cristallo uprizorili Pahorjevo novelo Rože za gobavca iz zbirke Grmada v pristanu. 
percipirati na ozadju specifičnega položaja in pomena slovenskega gledališča $\mathrm{v}$ Trstu, Pahorjeve pozne in postopne uveljavitve $\mathrm{v}$ slovenskem in italijanskem prostoru ter pisateljevega razmerja do gledališča ${ }^{10}$ oziroma njegove estetike, ki zavrača avantgardne - kot jih sam imenuje - oziroma postdramske/ne več dramske pristope.

Podobno prevlado izvenliterarnih razlogov za uprizoritev lahko opazujemo v drugem primeru Pahorjeve pričevanjske literature - v Nekropoli. Avtor dramatizacije in obenem režiser Boris Kobal se je s pričevanjsko literaturo o taboriščni izkušnji spoprijel že ob uprizoritvi Levijevega romana Ali je to človek v Mestnem gledališču ljubljanskem (2005/6), Pahorjev roman pa ga je nagovarjal dlje časa, a se je prava priložnost za njegov prenos v gledališki medij pokazala šele leta 2010, ko je Ljubljana postala deseta svetovna prestolnica knjige in je bila v sklopu projekta Knjiga in mesto posebna pozornost namenjena Borisu Pahorju.

Nekropola - Pahorjevo pričevanje s svojo specifično nekoherentno in fragmentarno strukturo, utemeljeno $\mathrm{v}$ naravi travmatskega spomina, $\mathrm{z}$ nizanjem podobnih situacij in portretov sotrpinov iz taborišča, zgoščenostjo izraza in s popolno odsotnostjo dialoga - v nasprotju z romanom Spopad s pomladjo ne ponuja dramatizacije v smislu dramsko zasnovanega besedila, ampak - podobno kot drugi pričevanjski teksti - $\mathrm{z}$ inherentno dramskostjo in performativnostjo implicira druge vrste prenosa v gledališki medij.

Pahor je bil skeptičen do ugledališčenja svoje literature že v Spopadu s pomladjo, sploh ker je od dramatizacije in njene uprizoritve pričakoval zvestobo literarni predlogi. V Nekropoli, tipičnem pričevanjskem tekstu, $\mathrm{v}$ katerem pisatelj poglobi nepomirljiv razdor med preteklostjo in sedanjostjo oziroma pozicijo taboriščnika in turista $\mathrm{v}$ taborišču ter izraža celo odpor in ljubosumje $\mathrm{e}^{11}$ zaradi zunanjega ogrožanja (zvedavi turisti, radoživ ljubezenski par, udeleženci kolesarske dirke ...) svetosti svojih občutkov in spominov, je bil avtor priredbe postavljen pred podobno ali celo odgovornejšo nalogo. Pahor v romanu problematizira tako moč fotografije kot filma, ko govori o »krematorijskem svetu «. Resnaisov film Nacht und Nebel (1955), ki je nastal po enako naslovljeni knjigi Pahorjevega sotrpina iz taborišča Andréja Ragota, označi kot preskopega v svojem izrazu: »Moral bi se bolj poglobiti v to življenje oziroma v to smrt« (Pahor, 1997, 156).

10 Pahor se je kmalu po vrnitvi iz taborišča vključil v gledališko življenje s pisanjem kritik gledaliških predstav. Njegove kritike odsevajo skrb za utrjevanje narodne pripadnosti, s čimer je povezano zavedanje o jeziku.

11 »Razumem, nekakšen nerazločen upor se prebuja v meni, upor proti temu, da je zdaj odprt in razgaljen ta planinski kraj, ki je sestavni del našega notranjega sveta; temu uporu pa je hkrati primešan občutek ljubosumja, ker ne samó, da se tuje oči sprehajajo po okolju, ki je bilo priča naše anonimne ujetosti, ampak turistovski pogledi (in tega se nezgrešljivo zavedam) ne bodo nikdar mogli prodreti v prepad zavrženosti, s katero je bila kaznovana naša vera $\mathrm{v}$ človekov ponos in v prostost njegovega osebnega odločanja« (Pahor, 1997, 7). 
Dvoglasnost - glas pričevalca in glas turistov - je tisti element, na katerem je Kobal zasnoval dramatizacijo, iz katere vznika dramska napetost ter se ohranja Pahorjevo značilno vzpostavljanje stalnega dinamičnega odnosa med preteklostjo in sedanjostjo. Nepomirljivost dveh časovnih perspektiv in dveh različnih pozicij (taboriščnik, turist) obvladuje celotno pripoved, izrazito pa zaznamuje njen začetek in konec. Zvonko Kovač in Ivana Latković (2011, 30-31) njun razcepljeni, dvodelni kompozicijski slog razumeta kot močan dokaz dvoma o ubeseditvi doživetega:

Pahorjev dvodelni memoarski glas (glas pričevalca in glas turistov) je združen v avtorjevem komentarju »da ne bi nikakor mogel govoriti skupini obiskovalcev, ko bi me poslušal nekdo, ki je bil z mano v krematorijskem svetu«, ker bi ga prevzel strah, da ne bi zašel v površnost.

Zavezanost resnici, ki izhaja iz pričevanjskega diskurza, in izrazita intenca po osveščanju (predvsem) mladih rodov o taboriščnem življenju prirejevalcu predstavljata tako izziv kot občutek nemoči oziroma manka ustvarjalne svobode. Kobal je svojo nalogo razumel predvsem v prvem pomenu, saj je ustvaril premišljeno strukturirano priredbo Pahorjevega avtobiografskega romana, ki zajema vse njegove bistvene poudarke; kljub temu pa - predvsem v fazi uprizoritve, ki je premalo izkoristila bogastvo gledaliških neverbalnih kodov - ne more uiti oznaki poenostavljene odrske ilustracije bistveno obsežnejšega in izjemno zgoščenega pričevanjskega gradiva. Če prebiranju besedila namenimo približno pet ur, nam njegovo esenco zajame priredba na petnajstih straneh oziroma uprizoritev v eni uri. Ob takšnem postopku - kljub temu da je opravljen skrbno - se ne moremo izogniti vprašanju o smiselnosti tovrstne priredbe. Upoštevajoč že navedene razloge, zaradi katerih je prišlo do dramatizacije, kot označi Kobal svojo priredbo, lahko najdemo njen glavni namen in pomen $\mathrm{v}$ didaktičnosti, ki se kaže v pričevanjskosti, opominjanju, spominjanju in opozarjanju (predvsem mladih generacij) na (preteklo) zlo. Čeprav je ob tem zaradi izpuščanja obsežnih opisov, refleksij, reminiscenc in tragičnih portretnih miniatur taboriščnikov iz romana prišlo do vtisa siromašenja, se je ravno s prenosom v gledališki medij moč Pahorjeve besede in sporočila povečala, saj je Pahor, ravno tako kot drugi pripovedniki pričevalci, negacija masovne kulture in "nikoli res popularen avtor« (Škrabec, 2011, 152).

Dramatizacija ohranja kronologijo nizanja spominskih fragmentov, obnavljanja doživetega in refleksij iz romana; kot pa je bilo že zapisano, prirejevalec črta številne spominske asociacije ali jih skrajša oziroma strne; mestoma uporabi tudi postopek kompilacije posameznih fragmentov iz romana. Kobalova dramatizacija skuša zajeti vse bistvene topose Pahorjevega romana (usode taboriščnikov, pričevalčeve moralne dileme, občutke krivde in nečistosti, nacionalno identiteto, strategije preživetja, razmerje med preteklostjo in sedanjostjo), ne zmore pa v tej svoji (zgolj) okleščeni 
obliki zajeti vse polnosti Pahorjevega izraza. Še bolj kot spomini na tragične zgodbe taboriščnikov namreč bralca presunejo metaforični ${ }^{12}$ in metonimični opisi ljudi (zebre, oslepeli ptiči, ki so jim požgali perje, voščeni vodni komarji, osmojeni pajki z iksastimi zadnjicami, plazilci, gole želvine glave, sivkasto-modre proge, nataknjene lobanje na vrhu črtastih palisad ...).

Začetek dramatizacije je umeščen znotraj taborišča in ne na pot vanj, kot se začne pripoved v romanu; gospod $\mathrm{P}$ s svojo zgodbo, v kateri bralca seznani $\mathrm{z}$ bistvenimi informacijami (krematorijski svet, ponovitev svojega obiska izpred petih let, želja po samotnem potovanju po »neslišnem svetu«), že takoj vzpostavi brezbesedni dialog, zapisan tako v glavnem kot v stranskem tekstu, s skupino turistov. Iz nje se izdvoji deklica na kotalkah kot simbol mlade generacije, ki ji je pripoved namenjena. Kadar pripovedovalec ne govori skupini na »odru«, pripoveduje publiki in s tem svoj monolog dialogizira. Nizanje reminiscenc o taboriščni izkušnji izpred dvajsetih let prekinjajo refleksije. Še izraziteje kot v romanu se v dramski predlogi enakomerno izmenjujeta preteklost in sedanjost, kar ne samo vnaša ritem, ampak postane strukturno načelo dramatizacije. Pripovedovalec svoje popotovanje znotraj taboriščne žice ubeseduje enako kot prvoosebni pripovedovalec/pričevalec $\mathrm{v}$ pripovedi, razlika je le $\mathrm{v}$ redukciji besedila.

Roman:

Spustil sem se po travnatem pasu, ki s paštna strmo pada k ograji iz bodeče žice. Tukaj, na koščku zemlje, ki ostaja med žico in vzpetino, je bila poleg greznice luknja za pepel (Pahor, 1997, 89).

\section{Dramatizacija:}

Tukaj, na koščku zemlje, ki ostaja med žico in vzpetino, je bila poleg greznice luknja za pepel (Kobal, 2009/10, 10).

$\mathrm{V}$ uprizoritvi je prišlo do približevanja zapisane besede živi govorici oziroma njeni skladnji:

Tukaj je bila greznica, zraven je bila poleg greznice luknja za pepel.

V uprizoritvi Nekropole, ki je zvesto sledila dramatizaciji, kar lahko pripišemo temu, da jo je napisala in režirala ista oseba, se je udejanjil princip uprostorjenja pričevanjske literature. Pripovedovalčevo/pričevalčevo izrekanje teksta je potekalo vzporedno z nekakšnim brezbesednim dialogom s skupino desetih turistov, ki je pogosto prevzela vlogo »ilustriranja» monodrame. Predstava je bila umeščena $\mathrm{v}$ Lapidarij na Ljubljanskem gradu, ki je s svojim razgibanim reliefom (stopnice) - ta

12 Na spojitev pričevanjskega verizma, ki na splošno prevladuje v pričevanjskih romanih, z izrazito imaginacijsko naracijo (metaforizirano, osebno ekspresivno, nadrealistično) opozori tudi Boris Paternu $(2014,40)$ 
spominja na taboriščne "paštne« - ter z betonskimi stebri priklical podobo taborišča $\mathrm{v}$ Vogezih. Taboriščno atmosfero sta še dodatno ustvarjala predirljiva luč, usmerjena $\mathrm{v}$ publiko, in mraz odprtega, prepišnega prostora.

Obe v prispevku obravnavani uprizoritvi dramskih besedil, nastali na osnovi Pahorjeve pričevanjske pripovedne proze, sta v smislu ozaveščanja (predvsem) mladih rodov dosegli svoj namen. Sploh predstava Nekropola je v svoji izraziti didaktičnosti pripomogla $\mathrm{k}$ ohranjanju oziroma vzpostavitvi individualnega in kolektivnega spomina na grozote holokavsta. Zgoščenost nizanja spominov in njihovo ponavljanje $\mathrm{v}$ romanu, ki bralca navdajata $\mathrm{z}$ grozo, sta dramatizacija in uprizoritev Nekropole nekoliko zreducirali, s čimer sta zmanjšali intenziteto izpovednosti, obenem pa sta taboriščno izkušnjo in njene posledice približali širši publiki. Preučevana primera sta pokazala, da bi bilo treba za izvirnejšo, bolj gledališkemu mediju prilagojeno in s tem tudi prepričljivejšo uprizoritev uporabiti drugačne strategije prirejanja romana - morda poiskati določene motive in dramatizacijo zasnovati na njih ali pa izkoristiti inherentno performativnost romanov. Vendar odločitev za tradicionalno dramsko in gledališko priredbo romana Spopad s pomladjo ter gledališko ilustracijo romana Nekropola ni povezana samo $\mathrm{z}$ dramatizatorskimi in režiserskimi koncepti avtorjev obeh dramatizacij ter uprizoritev, ampak tudi z zahtevami in pričakovanji avtorja romanov Borisa Pahorja.

\section{Bibliografija}

Bavčar, E., Boris Pahor: etika slovenstva, v: (Po)etika slovenstva: Družbeni in literarni opus Borisa Pahorja (ur. Pregelj, B., Kozak, J.), Koper 2011, str. 11-19.

Dolhar, P., »Vztrajal sem, da želim tradicionalno predstavo«, Primorski dnevnik, 21. december 2006.

Dolhar, P., Ipavec, M., Včasih se mi zdi, da so okrog mene sami televizorji, Pahorjevo stoletje - skupna priloga Primorskega dnevnika in Primorskih novic, 25.-26. avgust 2013, http://media.primorski.eu/media/attach/2013/08/BorisPahor_100.pdf [9. 10. 2018].

Herman, D. in dr., Routledge Encyclopedia of Narrative Theory, London, New York 2008. ${ }^{2}$

Jurič Pahor, M., O nuji, pripovedovati o Auschwitzu. Narativnost spominjanja in genotekst simbolizacije, v: Razprave in gradivo 56-57, Ljubljana 2008, str. 6-33.

Kobal, B., Nekropola (videogradivo Mestnega gledališča ljubljanskega), Ljubljana 2010. 
Kravos, B., Boris Pahor in Slovensko gledališče v Trstu, v: (Po)etika slovenstva:

Družbeni in literarni opus Borisa Pahorja (ur. Pregelj, B., Kozak, J.), Koper 2011, str. 285-296.

Lampret, I., Pahor, B., Spopad s pomladjo (tipkopisno gradivo), Trst 2006.

Latković, I., Kovač, Z., (Ne)izrekljiva izkušnja taborišča in smrti, v: (Po)etika slovenstva: Družbeni in literarni opus Borisa Pahorja (ur. Pregelj, B., Kozak, J.), Koper 2011, str. 27-41.

Marušič, B., Dramatizacija sodobnega slovenskega romana (doktorska disertacija), Ljubljana 2015.

Mermolja, A., Uprizoritev dela Borisa Pahorja Spopad s pomladjo - veliko dejanje, Primorski dnevnik, 27. december 2006.

Pahor, B., Nekropola, Ljubljana 1997.

Pahor, B., Kobal, B., Nekropola (tipkopisno gradivo), Ljubljana 2010.

Pahor, B., Spopad s pomladjo, Ljubljana 2009.

Paternu, B., Pahorjeva Nekropola, Jezik in slovstvo 2-3/2014, str. 29-41.

Pavis, P., Gledališki slovar, Ljubljana 1997.

Perne, A., Uprostorjenje pričevanja, Dnevnik, 14. junij 2010, str. 17.

Rojc, T., Spomin in zgodovinska stvarnost v delu Borisa Pahorja, v: (Po)etika slovenstva: Družbeni in literarni opus Borisa Pahorja (ur. Pregelj, B., Kozak, J.), Koper 2011, str. 73-82.

Sosič, M., Dnevnik, v: Boris Pahor. Spopad s pomladjo. Una primavera difficile (gledališki list), Slovensko stalno gledališče Trst, sezona 2006/7, Trst 2006.

Sosič, M., Spopad s pomladjo (videogradivo Slovenskega stalnega gledališča Trst), Trst 2006.

Škrabec, S., Ostrina pisave: Boris Pahor v evropskem okviru, v: (Po)etika slovenstva: Družbeni in literarni opus Borisa Pahorja (ur. Pregelj, B., Kozak, J.), Koper 2011, str. 139-155.

Verginella, M., Boris Pahor - pričevalec in razlagalec taboriščnega anus mundi, v: (Po) etika slovenstva: Družbeni in literarni opus Borisa Pahorja (ur. Pregelj, B., Kozak, J.), Koper 2011, str. 51-67.

Zupan, K., Uprizoritev Nekropole Borisa Pahorja, v: Ljubljanski knjižni pečat. Leto Ljubljane - svetovne prestolnice knjige 2010 (ur. Šumi, N.), Ljubljana 2011, str. 62-67. 
Breda Marušič

\section{Ugledališčenje spominov na primeru Pahorjevih romanov Spopad s pomladjo in Nekropola}

Ključne besede: Boris Pahor, spomini, pričevanjska literatura, koncentracijsko taborišče, gledališče

$\mathrm{V}$ prispevku preučujem uprizoritev oziroma ugledališčenje dveh Pahorjevih romanov - Spopad s pomladjo (1958) in Nekropola (1967). Zanima me razmerje med romanesknim literarnim besedilom, dramsko literarno predlogo, ki je nastala po njem, in uprizoritvijo.

Nekropola je roman, $\mathrm{v}$ katerem je Boris Pahor najbolj celostno ubesedil taboriščno izkušnjo, ki jo je fragmentarno tematiziral že v zbirki črtic Moj tržaški naslov (1948), prvič pa je o njej obširneje pisal v romanu Onkraj pekla so ljudje (1958).

Pahorjeva romana Spopad spomladjo (Onkraj pekla so ljudje) in Nekropola spadata v skupino pričevanjskih literarnih besedil o holokavstu, ki se distancirajo od »čistih" zgodovinskih besedil in poudarjajo subjekt izrekanja. Pahor prevprašuje človekovo zmožnost spominjanja in ubeseditve taboriščne izkušnje; edino filmska kamera bi lahko verodostojno posnela taboriščne sekvence, vendar - kot zapiše pisatelj - je bolje, da takega filma ne bi bilo. Kako globoko in prepričljivo je bil spomine zmožen prikazati gledališki jezik, pa je osrednje raziskovalno vprašanje mojega prispevka. 


\section{Breda Marušič}

\section{Dramatization of Boris Pahor's Memoirs Spopad s pomladjo in Nekropola}

Keywords: Boris Pahor, memoirs, testimonial literature, concentration camp, theatre

The aim of my article is to study the theatrical performances or dramatizations of two novels, written by Boris Pahor, Spopad s pomladjo (1958) and Nekropola (1967). I am interested in the relation between the prose text, its dramatic text, which is based on the former, and its theatrical performance.

Nekropola is the novel which best expresses Boris Pahor's experience in a concentration camp. The author discussed his experience in fragments in his collection of sketches Moj tržaški naslov (1948), whereas he extensively depicted it for the first time in his novel Onkraj pekla so ljudje (1958).

Pahor's novels Spopad s pomladjo (Onkraj pekla so ljudje) and Nekropola belong to testimonial literature about the Holocaust, which distance themselves from pure historic texts and stress personal experience. Pahor questions a man's ability to remember and express the experience of a concentration camp; only a film camera could reliably depict the scenes that take place at a concentration camp. However, the novelist suggests there should be no such films. The main issue of my article is to explore the depth and the plausibility of the theatrical language used in these works. 